\title{
Collaboration of Counseling Teachers and Parents in Distance Learning During The Covid- 19 Pandemic
}

\author{
Rio Hermawan, \\ Vocational High School 3 Kasihan \\ e-mail: riohermawan1990@gmail.com
}

\begin{abstract}
This research is a type of descriptive analytic study, which explains and analyzes how the collaboration of counseling teachers and parents in distance learning during the Covid-19 pandemic. During distance learning the bk teacher should consider increasing communication interaction with parents as well as collaborating with parents and trying to develop positive perceptions about students in terms of student success during distance learning. Collaboration is an activity where there is cooperation between various parties in realizing educational goals, both parties from within and from outside educational institutions. Collaboration in guidance and counseling is a collaborative activity between counseling teachers and a number of related parties in order to achieve the objectives of the guidance and counseling service program, therefore there is a need for a good collaborative strategy between counselors and parents, especially in terms of developing student study success. The involvement of parents in question can be in the form of inviting parents as members of the school committee, providing opportunities for parents to become tutors in an instructional program, involvement of parents in funding a broader school program and also strengthening the understanding and skills of parents regarding child and adult development.
\end{abstract}

\section{Keywords: collaboration, guidance and counseling teachers, parenting, distance learning}

\begin{abstract}
Penelitian ini merupakan jenis penelitian deskriptif analitik, yang menjelaskan dan menganalisis bagaimana kolaborasi guru BK dan orang tua dalam pembelajaran jarak jauh selama pandemi Covid-19. Selama pembelajaran jarak jauh guru bk harus mempertimbangkan untuk meningkatkan interaksi komunikasi dengan orang tua serta berkolaborasi dengan orang tua dan mencoba mengembangkan persepsi positif tentang siswa dalam hal keberhasilan siswa selama pembelajaran jarak jauh. Kolaborasi merupakan kegiatan terjalinnya kerjasama antara berbagai pihak dalam mewujudkan tujuan pendidikan, baik pihak dari dalam maupun dari luar lembaga pendidikan. Kolaborasi dalam bimbingan dan konseling merupakan kegiatan kolaboratif antara guru BK dengan sejumlah pihak terkait guna mencapai tujuan program layanan bimbingan dan konseling, oleh karena itu perlu adanya strategi kolaboratif yang baik antara konselor dan orang tua, terutama dalam hal mengembangkan keberhasilan belajar siswa. Keterlibatan orang tua yang dimaksud dapat berupa mengundang orang tua sebagai anggota komite sekolah, memberikan kesempatan kepada orang tua untuk menjadi tutor dalam suatu program pembelajaran, keterlibatan orang tua dalam mendanai program sekolah yang lebih luas dan juga memperkuat pemahaman dan keterampilan siswa. orang tua tentang perkembangan anak dan orang dewasa.
\end{abstract}

Kata Kunci: kolaborasi, guru bimbingan dan konseling, parenting, pembelajaran jarak jauh

\section{INTRODUCTION}

Covid-19 patients in Indonesia are increasing day by day based on the update. Cases of positive corona virus (Covid-19) Tuesday (15/9) increased by 3,507 people, bringing the total to 225,030 cases. Of the total, 161,065 were declared cured and 8,965 died. The addition of positive cases today is based on examining 42,636 specimens (covid19.kemkes.go.id.) The government issued a policy that is to stop the spread of Covid-19, one of which is diverting learning at school into learning at home.

The Covid-19 pandemic has changed the learning pattern that should have been faceto-face to distance learning or what is commonly called courage. Limited knowledge of the use of technology is one of the problems in this learning system. Parents and counseling 
teachers in this situation are required to guide their children in online-based learning. For parents of students who are accustomed to using technology it may not be a problem, but for parents of students who are not used to technology it becomes a challenge in guiding their children during this situation.

The application of online learning in the Covid-19 pandemic situation is not an easy problem. There are many problems that accompany online learning activities, one of which is the problem of learning completeness. So far, learning completeness is determined by the education unit by referring to the passing competency standards and considering the characteristics of students, the characteristics of subjects, and the conditions of the educational unit.

This is certainly not an easy thing for all elements of Education. The era of development guidance and counseling currently focuses on collaboration between counselors and school, community, professional and parent stakeholders who function to develop student potential and competence. What is the role of guidance and counseling teachers in collaboration with parents in dealing with the current state transition and this online learning system. Currently, the role of guidance and counseling focuses on collaboration between counselors / counselors and parents as stakeholders at home. Collaboration is an activity where there is cooperation between various parties in realizing educational goals, both parties from within and from outside educational institutions. Thus, collaboration is a concrete and systematic step in the educational environment which has a direct impact on improving the quality of education.

Parents are actually the main educators for students when they are outside the school environment. Parents are involved in the process of mutual communication about the BK program and the development of students. Parents also assist in data and information collection, and help the success of BK services with monitoring outside of school. The various roles above are important contributions in implementing the BK program in the era of distance / online learning effectively and efficiently.

The role of parents in schools is the spearhead of education in realizing educational goals as well as to deliver students to have and be able to develop their potential and competence. Therefore, parents as navigators whose function is to help direct students' development amid the Covid-19 pandemic, the complexity of distance learning problems faced by students during online learning.

Given the importance of collaboration between counseling teachers and parents in educating children, existing studies have proven that the collaboration between counseling teachers and parents has a very big share in children's abilities in the sphere of education. One of them is research conducted by Ariadi. N and Fuad.A.R., 2017. School counselors need to consider increasing interaction and collaboration with parents of students and trying to develop positive perceptions about students in terms of student success.

Therefore, it is necessary to collaborate between BK teachers and parents in guiding students during the distance learning process. Based on the description above, here school counselors need to have a good and appropriate collaboration strategy between parents, especially in terms of developing student success in school studies. Because the success of student studies in school will be difficult to achieve if there is no parent involvement in the development of their children at school.

\section{METHODS}

This article uses a descriptive analytic type, which describes and analyzes how the role of parents in Distance Learning and what efforts parents should make in guiding their child's Distance Learning. The type of data used in this article is secondary data obtained 
from literature, books, journals, reports, information about parents of students, information from homeroom teachers, and counseling teachers in the field. Data collection The technique used is library research (library research) by searching for and collecting secondary data from various references, including books, journals, the internet, parents of students, counseling teachers, and homeroom teachers whose validity can be noted. The analysis technique used in this article is the content analysis method, namely by explaining and analyzing existing sources, after which various references are linked to the research conducted.

\section{FINDINGS AND DISCUSSION Findings}

According to Gray (1989), collaboration is a thought process where the parties involved look at the different aspects of a problem and find solutions to these differences and the limitations of their views on what Grothaus, T., \& Cole, R. (2012). Meanwhile, according to Alwasilah, (2007). Collaboration is a teaching technique by involving peers to correct each other. Collaboration is a place to greet and stay in touch with knowledge. In addition there is shared learning (social learning).

Based on Permendikbud 111/2014, it is explained that collaboration is a fundamental activity of BK services where counselors or guidance and counseling teachers work together with various parties on the basis of the principles of equality, mutual understanding, mutual respect and mutual support. All collaborative efforts are directed at a common interest, namely how to ensure that each student / counselee achieves optimal development in aspects of personal, social, learning and career development.

Collaboration is carried out between counselors or guidance and counseling teachers with subject teachers, homeroom teachers, parents, or other relevant parties to build understanding and / or joint efforts to help solve problems and develop the potential of students / counselees.

School counselors have the main responsibility in developing comprehensive programs, but they cannot meet this global challenge without the help and support of other professionals, the school system, and the community (Bhakti, 2016).

Schmidt (2003) which states that school counselors who are expected to exist in the present and future are school counselors who can develop and design a program involving parents in their children's education programs in schools through collaborative activities.

In Hidayat (2013) it is explained that there are many groups and professionals who collaborate with schools to develop effective services for students. These groups are classified into two categories, namely school services and community agencies.

From Myrich's opinion (2011: 331), it can be seen that the consultation service process needs to be carried out through comprehensive collaboration between counselors, teachers, and parents in order to develop student competencies.

Collaborative guidance and counseling teachers by involving parents, namely in the form of inviting parents as members of the school committee, providing opportunities for parents to become tutors in an instructional program, involvement of parents in funding broader school programs and also strengthening parental understanding and skills with regard to child development and adults.

The collaboration method used by the guidance and counseling teacher is one of the supports for the smooth running of guidance and counseling service activities. The success of BK teachers in providing services depends on what methods are used in the BK services. Each method has its advantages and disadvantages.

Collaborative guidance and counseling is a process of intervention between several parties, namely through cooperation with the principal, teachers and parents of students in order to provide services to the counselee by changing their views, actions and atmosphere, understanding, realizing, maximizing and optimizing their potential maybe in a partnership relationship. 
Thus, through collaborative counseling with parents who are always awake will create conducive relationship patterns to be able to reach and expand counseling services to students. The counselor studies the parents and guardians of students at school. Collaboration with parents and guardians has a significant impact on direct counseling services with students.

Parents are actually the main educators for students when they are outside the school environment. Parents are involved in the process of mutual communication about the BK program and the development of students. Parents also assist in data and information collection, and help the success of BK services with monitoring outside of school.

Family is an important factor in the development of self-confidence, academic and life success of students. A number of literatures have shown that family, including socioeconomic status, parental involvement, and parental expectations, influence student learning development and career development (Weiser and Riggio 2010).

According to the opinion of Abu Ahmadi (2004: 43) states the role of parents is a complex matter of human expectations of how individuals should behave with responsibilities in the family. This means that the role of parents towards children has a lot of obligations and responsibilities, one of which is the field of education, both formal and non-formal. Where with education, children get an achievement or even become humans who are ready to face challenges in the future.

According to Ahmadi Abu (1991: 54), there are four points of function of children towards parents, namely:

1. The family is formed for the reproduction of offspring, which is a sacred religious duty which is imposed especially on humans.

2. Family travel must be responsible in the form of organized care of family welfare, nutritious food, and others.

3. In the family, it requires parents to organize socialization, providing a better direction for education for their children.

4. The inheritance of human values in the future can create people who live in peace and are able to maintain the quality and morality of the environment.

\section{Discussion}

Based on the results of the literature that has been done, it is found that collaboration between counseling teachers and parents during distance learning can produce a comprehensive plan. Collaboration is the process of discussing and sharing knowledge and information among members involved in collaboration. The role that collaboration partners can play is to create models, goals and strategies. To understand child development and other problems, counseling teachers need to use tools such as self-reports, interviews, tests, case histories, behavioral observations related to the implementation of collaborative services with collaborative partners.

For this reason, in collaboration services, BK teachers can invite parents to school to discuss further joint programs in an effort to achieve student development. Parents are actually the main educators for students when they are outside the school environment. Parents are involved in the process of mutual communication about the BK program and the development of students. Parents also assist in data and information collection, and help the success of BK services with monitoring outside of school.

Parents are actually the main educators for students when they are outside the school environment. Parents are involved in the process of mutual communication about the BK program and the development of students. Parents also assist in data and information collection, and help the success of BK services with monitoring outside of school. 
According to Efendi, et al. (2013). Collecting data and information on the success of BK services by monitoring outside the school during distance learning. needs to be fulfilled, there are the following implications that must be done, namely as follows:

1. Parents and community members (community groups from which students come) must be involved since the assessment process. Their involvement in this can be in the form of: being a source of accurate data on the situation (family background, educational background, socio-economic background) in the call for need.

2. Guidance services are not only provided for students, but also for all parties who will be seen in the student growth process. In other words, all parties who are important to the student development process are entitled to receive guidance and counseling services.

3. For BK teachers to increase their cooperation with other teachers in schools; in order to try to enter every existing BK professional organization; and to increase cooperation with other professional personnel.

Family is the birthplace of the seed of a generation with character and school is the place where that generation grows and develops. Given the role of parents currently in the era of the Covid 19 pandemic as the most important educators in the child's development, parents are true partners for educators. As parents, it is not enough just to stand outside the school fence observing the educational process of our children from afar. Of course, it takes hard work from two sides. Active and positive collaboration between parents and counseling teachers to succeed and harmonize educational programs developed by schools, including character education for our children. The following is a form of collaboration between parents at school (Sukiman et al, 2016):

1. Attend a meeting with the homeroom teacher on the first day of school

2. Attend a meeting with the homeroom teacher, at least twice a semester

3. Attend parenting classes at least twice a year

4. Present yourself at each report card distribution

5. Attend as a resource for the inspiration class

6. Be actively involved and attend class performances at the end of the school year

7. Be actively involved in the parent association in children's classes

Various parental collaborations in these schools can provide support and positive things for the development of students at school, and the reasons for the need for parental involvement in school activities (Sukiman et al, 2016):

1. Parents can better understand and support school programs

2. Parents can synchronize children's activities at home

3. Parents can share and increase knowledge in supporting the success of children's education

4. Parents can know and play an active role in anticipating various threats around children, such as violence, drugs, pornography, radicalism, and other immoral acts.

5. Parents can provide input for school progress

6. Parents can follow the progress of learning and provide support for children's progress

The following are the principles of family partnerships with schools (Sukiman et al, 2016):

1. Equal rights, equality and mutual respect

2. The spirit of mutual cooperation and togetherness

3. Completing and strengthening each other

4. Sharpening each other, loving each other, and nurturing each other.

\section{CONCLUSION}

Education during distance learning requires collaboration with various parties in various educational activities. Collaboration is an activity where there is cooperation between various parties in realizing educational goals, both parties from within and from outside educational institutions. School guidance and counseling programs also emphasize collaboration. The collaboration in the guidance itself involves various stakeholders, ranging 
from school principals, deputy principals, BK coordinators, BK teachers, subject teachers, homeroom teachers, administrative staff, school committees to parents.

Parents are actually the main educators for students when they are outside the school environment where students currently carry out their learning at home through online learning or distance learning. Parents are involved in the process of mutual communication about the BK program and the development of students. Parents also assist in data and information collection, and help the success of BK services with monitoring outside of school. The various roles above are important contributions in implementing the BK program in schools effectively and efficiently. So that various parental involvement in the school can provide support and positive things for the development of students in the school.

\section{ACKNOWLEDGMENT}

The completion of this paper cannot be separated from the assistance of all parties, both direct and indirect. On this occasion the author would like to thank all those who have helped the smooth writing of this article, especially to the editorial board of the Journal which has reviewed and provided suggestions for improvements in article writing so that it is worthy of being published in this edition. May God reward them all.

\section{REFERENCES}

Ahmadi, Abu. (1991). Sociology of Education. Jakarta: Rineka Cipta.

Bhakti, C, Safitri, N \& Rahman, F. (2016). Improving Quality Of Education Through Collaboration System In The Perspective Of Comprehensive Guidance And Counseling. Proceeding International Conferences On Education And Training, 2016, 1218-1223. Malang: Faculty Of Education State University Of Malang.

Efendi et al. 2013. The Influence of Leadership Behavior and Work Motivation of Principals on Increasing Pedagogic Competencies of SMAN Teachers. Pontianak: Journal of the Masters Program in Educational Administration, FKIP, Tanjungpura University.

Grothaus, T., \& Cole, R. (2012). Meeting the Challenges Together: School Counselor Collaborating with Students and Families with Low Income. Old Dominion University. Alwasilah et al. (2007). Anyway Write. Bandung: Qibla.

Hidayat, Sholeh. 2013. New Curriculum Development. Bandung: PT Remaja Rosdakarya Bandung.

Myrick, Robert D. 2011. Developmental Guidance and Counseling : A Practical Approach Fifth edition. Minneapolis : Educational Media Corporation.

Schmidt, John J. (2003). Counseling In School: Essential Service And Comprehensive Programs. Boston: Library Of Congress Cataloging.

Sukiman, Safitri et al. (2016). Being a Great Parent. Jakarta: Ministry of Education and Culture.

Weiser, D. A., \& Riggio, H. R. (2010). Family background and academic achievement: does self-efficacy mediate outcomes? Social Psychology of Education, 13, 367-383. 